\title{
CO-MANAGEMENT SUMBERDAYA LAUT \\ PELAJARAN DARI PENGELOLAAN MODEL CO-FISH DI KABUPATEN LOMBOK TIMUR, PROVINSI NUSA TENGGARA BARAT.
}

\author{
Ratna Indrawasih ${ }^{1}$
}

ABSTRAK

Secara teoritis, praktek pengelolaan sumberdaya laut secara co-management lahir sebagai kritik terhadap pengelolaan yang bersifat sentralistik, seperti yang selama ini dipraktekkan di Indonesia dan community-based management. Kedua praktek pengelolaan sumberdaya laut ini memiliki kelemahan, yang diantaranya disebabkan oleh ketiadaan sinergi antara pemerintah dengan masyarakat (user group). Praktek co-management sebagai alternatif untuk mendorong terjadinya sinergi antar semua stakeholder terkait dalam pengelolaan sumberdaya laut. Penelitian ini mencoba mempelajari penerapan Co-fish di Kabupaten Lombok Timur- Nusa Tenggara Barat, yaitu pengelolaan sumberdaya laut yang dilakukan dengan pendekatan co-management dengan melibatkan stakeholder terkait. Bagaimana mekanisme dan dampaknya terhadap masyarakat binaannya serta bagaimana kekuatan dan kelemahannya yang didasarkan pada prinsip pendekatan co-management. Penelitian ini dilakukan melalui pendekatan kualitatif.

\section{Kata Kunci : Sumberdaya Laut, Ko-Manajemen, Lombok Timur.}

\section{Abstract : Co-management of Marine Resource : Lesson Learnt from the Management Model of Co-Fish in Lombok Timur District, Nusa Tenggara Barat Province. By : Ratna Indrawasih.}

Theoritically, the practice of marine resource management was created as a criticied of centralistic management wich being, that was practiced in Indonesia for a long time, and community-based management. Both of these practices of marine resource management have weaknesses, caused by the inexistance of cooperation between government and society (user group). The practice of co-management is an alternative option to push a cooperation among all of related stakeholder in marine resource management. The research to study the implementation of Co-Fish in Lombok Timur District, Province of Nusa Tenggara Barat. Marine resources management was carried out by co-management approach involving related srakeholders. The mechanism and impact of the implementation of Co-fish to the society, and how the strengths and weaknesses of Co-fish based on principal of co-management approach were analsed with qualitative approach.

\section{Keyword : Marine Resource, Co-Management, Lombok Timur.}

\section{PENDAHULUAN}

Pengelolaan sumberdaya laut yang telah dilakukan selama ini, baik oleh pemerintah maupun masyarakat tampaknya belum menemukan hasil sesuai yang diharapkan. Pengelolaan sumberdaya laut yang dilakukan oleh pemerintah selama ini bersifat sentralistik. Sebagaimana diketahui, bahwa dukungan terhadap praktek manajemen yang sentralistik diberikan oleh teori-teori yang mengakar pada konsep-konsep kepemilikan sumberdaya alam seperti Hardin (1968) dengan konsepsinya mengenai the tragedy of the commons, Gordon (1954) dengan konsepsi mengenai private ownership dan Scott (1955) dengan konsepsinya mengenai pemilikan tunggal. Teori-teori ini mendasari manajemen sumberdaya alam yang sentralistik karena kalaupun kemudian hak penguasaan terhadap sumberdaya alam itu didistribusikan kepada berbagai pihak, tetapi pemerintahlah yang mengatur pendistribusian hak-hak tersebut setelah mendefinisikan bahwa laut dikuasai negara. Selain itu, dalam rejim manajemen seperti ini, segala instrumen

\footnotetext{
1 Peneliti Pusat Penelitian Kemasyarakatan dan Kebudayaan -LIPI
} 
manajemen ditentukan oleh pemerintah, aktor lain yang terlibat dalam pengelolaan diharuskan tunduk kepada segala aturan yang ditetapkan pemerintah itu. Kritik, baik pada tataran diskursus teoritis maupun praktek manajemen yang sentralistik kemudian berkembang seiring dengan perkembangan kajian-kajian teoritis maupun terkumpulnya data dari pelaksanaan manajemen di lapangan (Adhuri dan Indrawasih, 2003).

Mempelajari hasil-hasil penelitian mengenai pengelolaan sumberdaya laut oleh pemerintah di Jawa Tengah, diketahui bahwa pengelolaan sumberdaya laut dilakukan oleh pemerintah secara sentralistik yang bertumpu pada kebijakan pemerintah, kontrol atas pelaksanaan peraturan tidak bisa dilakukan sepenuhnya. Kurangnya kontrol atau pengawasan pelaksanaan peraturan pengelolaan sumberdaya laut di lapangan (pengawasan di laut) disebabkan oleh kendala pembiayaan, karena memerlukan biaya cukup besar yang selama ini belum bisa terpenuhi (Indrawasih, 2004). Demikian juga hasil penelitian di Madura-Jawa Timur, terbatasnya dana, kondisi wilayah yang sulit diakses, terbatasnya fasilitas untuk melaksanakan pengawasan di laut menyebabkan pengawasan terhadap penggunaan alat penangkap ikan yang melanggar peraturan (bom dan racun) kurang maksimal. Akibatnya, Perda Kabupaten Sumenep Nomor 8 Tahun 2003 Pasal 16 yang melarang penangkapan ikan dengan bahan peledak dan bahan beracun belum dapat diimplementasikan secara maksimal.

Masalah lain sehubungan dengan pengelolaan sumberdaya laut oleh pemerintah secara sentralistik seperti yang dikemukakan oleh Balanda dan Platteau (1996), untuk kasus Indonesia lihat Bailey dan Zerner (1992), adalah kebutuhan biaya yang sangat besar untuk mengumpulkan data yang cukup dan akurat tentang kondisi sumberdaya, untuk mengadakan alat-alat monitoring, kecenderungan pembangkangan oleh pengguna sumberdaya karena ketiadaan hubungan yang 'dekat' antara user group dengan pemerintah, sub-ordinasi kepentingan lingkungan oleh kepentingan ekonomi dan politik pemerintah dan lain-lain (Adhuri dan Indrawasih, 2003).

Kebijakan pengelolaan sumberdaya laut yang dilakukan oleh pemerintah itu dibuat tanpa memperhatikan aspirasi masyarakat. Akibatnya banyak kepentingan masyarakat yang tidak terwakili, sehingga sering apa yang dianggap baik oleh pemerintah belum tentu dianggap baik oleh masyarakat Melalui kebijakan yang bersifat open access misalnya, nelayan lokal harus bersaing dengan nelayan pendatang yang memiliki tingkat teknologi yang lebih tinggi. Akibatnya adalah terjadinya persaingan yang tidak imbang, sehingga nelayan lokal berada dalam posisi yang kalah. Kebijakan yang bertumpu pada peran negara, yang diwujudkan dalam bentuk peraturan dan penerapannya, di satu sisi bisa dipahami, karena negara merupakan lembaga sentral yang memiliki hak untuk menguasai dan mendistribusikan sumberdaya yang ada, termasuk mengembangkan kebijakan dalam pemanfaatannya. Akan tetapi, pada sisi yang lain, tanpa adanya dukungan masyarakat, maka kebijakan yang demikian cenderung mengalami kegagalan. Selain itu, programprogram yang disusun oleh pemerintah cenderung berorientasi pada proyek dan bersifat sektoral, sehingga hasilnya kurang optimal.

Kritik terhadap teori-teori di atas telah mengarahkan perhatian para ahli pada praktek-praktek hak ulayat (communal property). Keberadaan praktek hak ulayat laut telah membuat harapan para ahli akan efektifitas dari praktek ini dalam mengolah sumberdaya laut. Harapan ini lahir karena ternyata asumsi Hardin (1968) bahwa manusia cenderung bergerak sendiri-sendiri untuk mengeruk keuntungan dari sumberdaya alam tidak lah benar. Hak ulayat membuktikan bahwa masyarakat mampu bekerja sama untuk menahan diri dari tindakan mengeksploitasi sumberdaya alam secara 
membabi-buta. Berbagai penelitian berkembang menganalisa hal ini. Hasilnya banyak berupa dukungan untuk menggunakan praktek-praktek hak ulayat laut sebagai dasar manajemen karena temuantemuan mereka menunjukkan efisiensi dari praktek-praktek ini. Beberapa kelebihan yang dicatat adalah bahwa (1) masyarakat lebih dekat dengan sumberdaya alam (laut) yang diaturnya karena itu mereka dianggap mengetahui banyak tentang kondisi sumberdaya alam (laut). (2) Masyarakat juga ternyata mampu membuat institusi yang memungkinkan mereka mengatur pemanfaatan dan pemeliharaan sumberdaya alam (laut) secara efisien dan distribusinya merata (equity). (3) Hubungan-hubungan personal yang terjalin antar anggota komunitas mengarahkan pada terbentuknya pola-pola kerjasama yang baik di antara mereka (ini juga berarti konflik lebih mudah diatasi). (4) Karena fungsi manajemen dilakukan sendiri oleh komunitas lokal, biaya pelaksanaan manajemen juga relatif rendah (diskusi lebih detail mengenai hal-hal di atas bisa dilihat misalnya Johannes (1978), untuk kasus Indonesia lihat Bailey dan Zerner (1992). Kecenderungan ini pada akhirnya telah mengembangkan dukungan terhadap pola manajemen yang disebut communitybased management. Tentu saja seperti juga pengembangan teorinya, dia dipertentangkan dengan government centralised management system (Adhuri dan Indrawasih, 2003).

Namun demikian community-based management juga mengalami nasib yang sama seperti halnya manajemen pendahulunya, manajemen yang tersentralisasi pada pemerintah. Berbagai penelitian menunjukkan kelemahankelemahan sistem ini. Hasil penelitian di Lombok Barat -NTB menunjukkan bahwa meskipun ada pengelolaan sumberdaya laut oleh masyarakat yang diatur dalam awig-awig, akan tetapi akibat kurang proaktifnya pemerintah daerah Kabupaten Lombok Barat merespons aspirasi yang berkembang dalam masyarakat agar pemerintah mengukuhkan melalui peraturan daerah, sehingga memiliki kekuatan hukum. maka pengelolaan yang berbasis masyarakat menghadapi permasalahan. Permasalahan yang dihadapi masyarakat nelayan Desa Sekotong, Kecamatan Sekotong Barat, Kabupaten Lombok Barat, Propinsi Nusa Tenggara Barat. yakni kerusakan lingkungan, merosotnya hasil tangkapan, dan konflik nelayan (lihat Adhuri., 2008).

Dari gambaran permasalahan yang muncul pada pengelolaan sumberdaya laut yang dilakukan oleh masing-masing stakeholder di atas, yaitu pemerintah dan masyarakat secara sendiri-sendiri, tampaknya tidak efektif. Kesimpulan ini lah yang merupakan salah satu titik tolak berkembangnya pemikiran bahwa dengan kelebihan dan kelemahan masing-masing pihak maka terdapat kemungkinan bahwa jika mereka dikondisikan bekerja bersama untuk kepentingan mereka bersama, maka kemungkinan mereka bisa berbagi kelebihan dan mengkoreksi kelemahan masing-masing. Artinya, jika mereka dikoordinasikan untuk bekerja sama, maka mungkin mereka akan saling membantu untuk hal yang baik dan saling mengawasi dan mengkoreksi untuk hal yang buruk. Begitulah kajian-kajian teoritis dan praktek co-management telah meyakinkan bahwa manajemen seperti ini dapat digunakan untuk mengurangi, kalau tidak menghilangkan, aspek-aspek negatif atau kekurangan dari manajemen yang dikontrol sepenuhnya oleh pemerintah pada satu sisi dan masyarakat pada sisi yang lain. Contoh dari keuntungan yang dilahirkan dari bentuk kerjasama tersebut, misalnya, kesulitan pemerintah untuk mengakumulasi data karena tidak terlibat langsung dalam kegiatan eksploitasi bisa ditutupi oleh pasokan data dari masyarakat pengguna. Sementara itu pemerintah, dengan kemampuan para ahli untuk mengelola data tersebut, dapat menginformasikan kondisi sumberdaya dan kemudian merumuskan program-program 
manajemen yang sesuai dengan masyarakat atau stakeholder lain. Begitu pula halnya dengan pengawasan dari pelaksanaan aturan-aturan yang disepakati dalam sistem manajemen tersebut. Masyarakat bisa diminta untuk melakukan pengawasan langsung di lapangan mengenai pelaksanaan aturanaturan yang disepakati. Dengan demikian pemerintah tidak harus mengeluarkan biaya ekstra untuk melakukan kontrol/pengawasan di lapangan (laut), apalagi untuk wilayahwilayah yang sulit dijangkau aparat.

Menyadari pentingnya pengelolaan sumberdaya laut yang demikian, pemerintah melalui Departemen Kelautan dan Perikanan, sejak tahun 1998 telah merintis pendekatan co-management dalam pengelolaan sumberdaya laut, melalui Proyek Pembangunan Masyarakat Pantai dan Pengelolaan Sumberdaya Perikanan (Coastal Community Development and Fisheries Resources Management Project), yang disingkat Co-Fish. Menurut keterangan informan dari Departemen Kelautan dan Perikanan (yang terlibat dalam menangani proyek Co-Fish) bahwa proyek ini dilaksanakan di lima kabupaten yaitu Bengkalis, Riau; Tegal, Jawa Tengah; Trenggalek (Prigi) dan Banyuwangi (Muncar), Jawa Timur; Lombok Timur (Selong), Nusa Tenggara Barat. Melalui proyek ini, maka pengelolaan sumberdaya laut dilakukan oleh suatu kelompok yang dibentuk pemerintah, seperti contohnya kelompok PSBK (Pengelolaan Sumberdaya Berdasarkan Komunitas) di Tegal (Jawa Tengah) dan KPPL (Komite Pengelolaan Perikanan Laut) di Lombok Timur-Nusa Tenggara Barat, yang anggotanya terdiri dari para stakeholder.

Keterlibatan stakeholder dalam perumusan kebijakan pengelolaan itulah maka pendekatan dalam proyek ini dapat dikategorikan sebagai pendekatan comanagement. Berkaitan dengan penerapan pendekatan co-management dalam proyek tersebut, maka bagaimana kekuatan dan kelemahannya inilah yang akan dibahas dalam tulisan ini.

\section{METODOLOGI}

\section{A. Lokasi Penelitian}

Penelitian dilakukan di Kabupaten Lombok Timur, Nusa Tenggara Barat. Pemilihan lokasi terutama didasarkan pada alasan bahwa daerah tersebut merupakan salah satu lokasi program Co-fish, yaitu pengelolaan sumberdaya laut yang dilakukan dengan pendekatan co-management dengan melibatkan berbagai stakeholder, yang dihimpun dalam satu kelembagaan yang disebut KKPK (Komite Kelautan Perikanan Kabupaten) untuk tingkat kabupaten dan KPPL (Komite Pengelolaan Perikanan Laut) di tingkat kawasan dan desa. Selain itu, di daerah ini sebelum dijadikan lokasi Co-Fish, merupakan daerah yang telah menerapkan community based-management

\section{B. Pengumpulan Data}

Penelitian ini bersifat kualitatif, tahapan penelitian mulai dari pengumpulan data, hingga analisis data dilakukan sesuai dengan prinsip-prinsip pendekatan kualitatif. Pengumpulan data dilakukan melalui wawancara mendalam (indepth-interview). Peneliti melakukan wawancara secara langsung dengan pihak-pihak terkait yang dapat menunjang keberhasilan penelitian dengan berpedoman pada panduan wawancara (interview guide). Untuk memperoleh gambaran mengenai kelebihan dan kelemahan praktik pengelolaan yang dilakukan, pengambilan data primer juga dilakukan dengan cara diskusi kelompok berfokus (focus group discussion). Selain itu, juga dilakukan observasi, yaitu sebagai teknik untuk melengkapi data-data yang terkumpul melalui teknik wawancara. Atau sebaliknya, teknik observasi digunakan untuk menstimulus pengembangan pengumpulan data atau informasi pada saat wawancara dilakukan.

Pemilihan informan dilakukan secara purposif, yaitu para stakeholder dalam pengelolaan sumberdaya laut, terutama yang terlibat dalam Co-Fish yang meliputi: unsur 
pemerintah (Departemen Kelautan dan Perikanan, Dinas Perikanan Propinsi dan Kabupaten, Biro Hukum, Biro Ekonomi dan Lingkungan Hidup, Bappeda, Kecamatan, Kelurahan), industri perikanan (pengusaha/pengolah hasil laut), masyarakat nelayan (nelayan dari berbagai jenis dan tingkat teknologi), KUD, pengelola TPI (Tempat Pelelangan Ikan), BPPPI (Badan Pengelola Pangkalan Pendaratan Ikan). Selain itu adalah aktivis LSM terutama yang terlibat dalam proyek Co-Fish serta kalangan perguruan tinggi juga yang terlibat dalam proyek tersebut.

\section{Pengolahan dan Analisis Data}

Data-data yang telah terkumpul, baik data sekunder maupun primer dikategorikan, dicari kesesuaian polanya, dan kemudian dianalisis secara naratif. Analisis naratif ini membantu mengidentifikasi hubungan kausal sebuah fenomena sehingga didapatkan gambaran yang rinci dari sebuah fenomena. Sesuai dengan pendekatan kualitatif, analisis data tidak menggunakan kalkulasi-kalkulasi kuantitatif. Data kuantitatif hanya sebagai data pendukung. Analisis data juga dilakukan secara deskriptif analitis dan dibandingkan dengan teori-teori yang dijadikan acuan dalam penelitian ini. Dengan demikian, dapat dihasilkan analisis yang komprehensif dan mudah dipahami.

\section{HASIL DAN PEMBAHASAN}

\section{A. Hasil Penelitian}

\section{Co-Fish (Coastal Community} Developoment and Fisheries Resources Management Project)

Co-Fish atau Proyek Pembangunan Masyarakat Pantai dan Pengelolaan Sumberdaya Perikanan bertujuan (1) meningkatkan pengelolaan sumberdaya perikanan pantai secara berkelanjutan, dan (2) mengentaskan kemiskinan masyarakat pantai melalui penyediaan kesempatan kerja, peningkatan pendapatan dan kualitas hidup.
Dalam kegiatan Co-Fish ini berkaitan dengan stakeholder termasuk organisasi pengelola dan tenaga pendamping serta jenis dan cara pengelolaannya.

\subsection{Stakeholder}

Stakeholder yang dimaksud dalam hal ini adalah beberapa pihak yang berkepentingan terhadap pengelolaan dan pemanfaatan termasuk kelestarian sumberdaya laut di wilayah Kabupaten Lombok Timur, baik secara langsung maupun tidak langsung. Stakeholder yang secara langsung dalam pengelolaan dan pemanfaatan sumberdaya laut khususnya sumberdaya perikanan adalah nelayan, sedangkan stakeholder yang tidak secara langsung adalah pedagang ikan, pengolah/industri perikanan, lembaga pemerintah dan beberapa jenis kelembagaan yang lain seperti KUD serta perguruan tinggi dan LSM.

Pemerintah daerah dalam hal ini mulai dari tingkat desa, kecamatan, kabupaten, provinsi, termasuk Dinas Kelautan dan Perikanan tingkat kabupaten dan provinsi hingga tingkat pusat (Departemen Kelautan dan Perikanan).

\subsection{Organisasi Pengelola}

Proyek Co-fish tersebut merupakan proyek pemerintah pusat yang pendanaannya berasal dari Asian Development Bank (ADB) dan Anggaran pendapatan dan Belanja Negara (APBN) dalam rangka merealisasikan visi pembangunan kelautan dan perikanan. Secara garis besar, struktur organisasi Co-fish berjenjang dalam tiga tingkatan, yaitu tingkat pusat, tingkat provinsi dan tingkat kabupaten. Disamping itu ada juga organisasi pengelola di tingkat kawasan dan desa.

\subsection{Tenaga Pendamping}

Dalam hampir seluruh kegiatan Co-fish juga didukung oleh tenaga pendamping, baik dari tim proyek (Bagian proyek Pembangunan Masyarakat Pantai dan Pengelolaan 
Sumberdaya Perikanan/BP2MP2SP) maupun dari LSM dan perguruan tinggi (Fakultas Perikanan Universitas Gunung Rinjani, Universitas 45 Mataram). LSM yang dilibatkan dalam kegiatan Co-fish di Kabupaten Lombok Timur antara lain Yayasan Laut Biru di Mataram, Yayasan Sumberdaya Dan Lingkungan Untuk Pelestarian Pembangunan (YSLPP) di Lombok Barat, dan Lembaga Penelitian dan Pengembangan Sumberdaya (LP2SD) di Lombok Timur (Selong).

\subsection{Pengelolaan Sumberdaya Laut}

Kegiatan pengelolaan sumberdaya laut yang telah dilakukan dalam proyek Co-fish di Kabupaten Lombok Timur terdiri dari 4 (empat) paket kegiatan yaitu :

a. Pengelolaan keanekaragaman hayati, yaitu merupakan kegiatan yang termasuk dalam komponen Pengelolaan Sumberdaya Perikanan Pantai (Coastal Fisheries Resource Management/CFRM).

Keseluruhan kegiatan yang termasuk dalam komponen CFRM meliputi kampanye aneka ragam hayati perikanan melalui berbagai media, mengembangkan kawasan suaka, pengamanan kawasan perikanan, mereklamasi mangrove dan terumbu karang, pelatihan pengawasan dan pengendalian berbasis patisipasi masyarakat, pelatihan pengelolaan sumberdaya ikan bagi KPPL (Komite Pengelolaan Perikanan Laut), Komite Penasehat Perikanan Lokal (FLAC), dan pendampingan LSM untuk pengelolaan keanekaragaman hayati perikanan.

b. Perbaikan lingkungan dan pusat pendaratan ikan (Environmental Improvement and Fish Landing Centres/IFLC)

c. Pengembangan usaha ekonomi, yaitu termasuk dalam komponen Pengembangan Masyarakat dan Pengentasan Kemiskinan (Community Development and Poverty Reduction/CDPR). Kegiatannya meliputi pengembangan budidaya perikanan dan pelatihan kelompok usaha dan budidaya, kredit dan usaha mikro, pelatihan ketrampilan perbaikan kapal serta pendampingan KUB dalam mengelola usaha.

d. Penguatan kelembagaan (Institutional Strengthening / IS) terdiri dari berbagai kegiatan untuk meningkatkan kemampuan institusi internal dan eksternal (KPPL, KUB, LKMP dan sejenisnya)

\subsubsection{Wilayah Pengelolaan}

Secara fisik perairan yang menjadi wilayah pengelolaan program Co-fish di Lombok Timur adalah mulai dari perairan di sebelah Utara Pulau Lombok bagian Timur, perairan Selat Alas dan 3 (tiga) kawasan teluk, yaitu Teluk Jukung, Teluk Serewe, dan Teluk Ekas. Teluk Jukung adalah sebuah teluk yang berada di wilayah Selat Alas, yang wilayah lautnya mulai dari UPBM sampai dengan Tanjung Pokki. Desa-desa yang berada dalam wilayah pesisir Teluk Jukung adalah desa Tanjung Luar, Pijot, Jerowaru dan Pemongkong. Teluk Ekas berada di sebelah selatan, yaitu mulai dari ujung Wengkek sampai dengan ujung Sanguak, yang berada dalam wilayah Desa Batunampar, Sukaraja dan Pemongkong, sedangkan Teluk Serewe berada dalam wilayah Desa Serewe. Selat Alas adalah perairan yang berada disebelah Timur Lombok Timur, yaitu membatasi wilayah Kabupaten Lombok Timur dan Kabupaten Sumbawa.

Secara administratif kelima wilayah pengelolaan tersebut di atas merupakan wilayah perairan dari 21 (duapuluh satu) desadesa pantai di Lombok Timur yang terbagi dalam 6 (enam) kecamatan, yaitu 4 (empat) desa di Kecamatan Jerowaru, 2 (dua) desa di Kecamatan Keruak, 2 (dua) desa di Kecamatan Sakra Timur, 5 (lima) desa di Kecamatan Labuhan Haji, 5 (lima) desa di Kecamatan Pringbaya dan 3 (tiga) desa di Kecamatan Sambelia.

Pada tahap pertama Co-fish dilakukan di kawasan ketiga teluk (Teluk Ekas, Jukung dan 
Serewe), baru kemudian menyusul di perairan Selat Alat bagian Utara (sebelah Timur Laut Pulau Lombok), yaitu wilayah perairan Kecamatan Sambelia, Lombok Timur bagian Utara. Sebagai desa target pertama proyek Co-fish adalah 6 desa pantai yaitu desa Batunampar, Jerowaru, Pemongkong, Sukaraja, Tanjung Luar dan desa Pijot. Keenam desa ini dulu masuk wilayah Kecamatan Keruak, tetapi dengan adanya pemekaran kecamatan baru pada tahun 2000, maka menjadi terpisah. Dua desa yaitu Tanjung Luar dan Pijot tetap masuk Kecamatan Keruak, sedangkan empat desa lainnya masuk dalam Kecamatan Jerowaru. 15 (limabelas) desa lainnya adalah Desa Sambelia, Belanting dan Obel-obel di Kecamatan Sambelia, Desa Kerumut, Pohgading, Batuyang, Pringbaya, dan Labuhan Lombok di Kecamatan Pringbaya, Desa Labuhan Haji, Peneda Gandor, Korleko, Kelurahan Suryawangi dan Kelurahan ljobalit di Kecamatan Labuhan Haji, serta Desa Surabaya dan Desa Gelanggang di Kecamatan Sakra Timur. Setelah 21 (duapuluh satu desa) di Kabupaten Lombok Timur, binaan Co-fish meluas ke Kabupaten Lombok Barat 2 (dua) desa dan 5 (lima) desa di Kabupaten Sumbawa.

\subsubsection{Kegiatan Pengelolaan}

Kegiatan pengelolaan yang dilakukan bermacam-macam, antara lain berupa pengelolaan wilayah dan sumberdaya seperti suaka perikanan, kawasan konservasi laut, rehabilitasi hutan mangrove dan terumbu karang, pengembangan silvo fisheries yang semua ini termasuk dalam kegiatan keanekaragaman hayati. Selain itu juga pelatihan-pelatihan dan pemberian pinjaman dana bergulir untuk modal usaha bagi kelompok usaha bersama (KUB), serta pelatihan-pelatihan kepada KPPL dalam kegiatan penguatan kelembagaan.

\section{a. Keanekaragaman hayati perikanan.}

Pengelolaan yang dilakukan dalam kegiatan keanekaragaman hayati perikanan ini antara lain meliputi penataan suaka perikanan (Fish Sanctuary), rehabilitasi hutan mangrove dan terumbu karang, pengembangan budidaya kepiting bakau (kepiting hijau), dan penataan kawasan konservasi laut (Marine Protection Area disingkat MPA).

\section{- Suaka Perikanan (Fish Sanctuary)}

Suaka Perikanan ini perlu dibentuk karena telah terjadinya kerusakan ekosistem dan punahnya sumberdaya perikanan akibat penangkapan berlebih (overfishing) maupun penangkapan ikan dengan cara yang merusak. Dengan adanya suaka perikanan diharapkan dapat meningkatkan produksi perikanan di sekitar kawasan suaka dan dalam jangka panjang dapat meningkatkan kualitas hidup masyarakat yang menjaga dan mengelola suaka perikanan. Setiap kawasan suaka dibagi menjadi zona inti dan zona penyangga. Di dalam kawasan tersebut dilarang melakukan semua kegiatan eksploitasi, sementara kegiatan non eksploitatif seperti bersampan dan budidaya masih diperbolehkan dilakukan tetapi hanya di zona penyangga.

\section{- Rehabilatasi Hutan Mangrove dan TerumbuKarang}

Berdasarkan hasil studi yang dilakukan di wilayah perairan kecamatan Keruak dan Jerowaru (yang menjadi target pertama kegiatan Co-fish) yaitu Teluk Ekas khususnya pantai Ekas dan Batunampar, Teluk Jukung dan Teluk Serewe, diketahui bahwa banyak lokasi hutan mangrove yang sudah dikonversi menjadi tambak garam dan tambak ikan. Luas tambak garam dan ikan yang berada dekat hutan mangrove tersebut justru lebih luas dibanding hutannya. Mengingat kondisi hutan mangrove dan terumbu karang seperti tersebut, maka Co-fish dalam salah satu kegiatannya pada tahun 2002 melakukan rehabilitasi hutan mangrove, yaitu dengan menanam 50 ribu pohon mangrove pada 
10 hektar di wilayah perairan Teluk Serewe, Teluk Ekas dan Teluk Jukung. Selain itu menanam terumbu karang buatan sebanyak 400 unit di tiga kawasan tersebut. Kemudian pada tahun 2003 merehabilitasi hutan mangrove seluas 75 hektar, yaitu 30 hektar di Gili (Pulau) Petagan (pulau yang berada di kawasan Selat Alas, 20 hektar dipantai Serewe (dusun Serewe, Desa Pemongkong) 10 hektar di pantai Pengoros (dusun Pengoros, desa Pemongkong), dan 15 hektar di pantai Ujung (dusun Ujung, desa Pemongkong) (Tim Peneliti Fakultas Perikanan Universitas Mataram, 2000).

\section{- Pengelolaan Sea Ranching Spat Mutiara}

Pengelolaan sea ranching tersebut khususnya di wilayah perairan Teluk Ekas, yaitu di lokasi Suaka Perikanan Sapak Kokok yang dilaksanakan pada tahun 2003. Dalam pengelolaan sea ranching ini, desa-desa di pesisir Teluk Ekas yang terlibat adalah Desa Batunampar, Sukaraja dan Pemongkong, Kecamatan Pembantu $\mathrm{J}$ e rowaru, serta Des a Bilelando,Kecamatan Praya Timur (Lombok Tengah). Dalam rangka pengelolaan sea ranching juga dibuat peraturan/ awig-awig

- Kawasan Konservasi Laut (Marine Protected Area)

Pada akhir tahun 2003, dilakukan penataan kawasan konservasi laut (MPA) di 3 (tiga) kawasan perairan pantai Gili (Pulau) Lawang (seluas $400 \mathrm{Ha}$ ), Gili Sulat dan Gili Petagan (seluas $1200 \mathrm{Ha}$ ). Penataan kawasan konservasi laut ini dilakukan karena terjadi penurunan sumberdaya perikanan di kawasan pantai Kecamatan Sambelia. Habitat ikan dikawasan tersebut juga banyak yang sudah rusak. Sebagaimana suaka perikanan, MPA juga bermanfaat dalam menyediakan tempat bertelur larva ikan (juvenile), atau tempat ikan bersembunyi dari penangkapan yang berlebihan. Di dalam kawasan MPA tersebut terdapat ekosistem yang meliputi padang lamun, mangrove serta terumbu karang dan ikan karang. Di kawasan dalam MPA, semua kegiatan yang bersifat ekstraktif (eksploitasi) dikendalikan secara ketat. Untuk penataan kawasan konservasi tersebut, masing-masing kawasan memiliki tiga zona yaitu zona inti, zona penyangga dan zona pemanfaatan.

Tujuan dibentuknya kawasan MPA, sebagaimana yang tercantum dalam laporan akhir Penataan Kawasan Konservasi Laut (MPA) di Kabupaten Lombok Timur ( Tim Peneliti YSLPP, 2003) adalah :1). Melindungi sebagian (>20\%) kawasan laut dari kegiatan eksploitasi dan menjaga stok larva dan sumberdaya ikan dewasa; 2). Memfasilitasi tersusunnya kesepakatan masyarakat dalam penetapan beberapa habitat ikan sebagai kawasan konservasi laut, untuk mengendalikan secara ketat kegiatan eksploitasi; 3) meningkatkan pengetahuan dan keterampilan Komite Pengelolaan Perikanan Laut (KPPL) dalam melaksanakan kewajibannya sebagai pengelola sumberdaya perikanan.

\section{- Pengembangan Silvo Fisheries}

Berdasarkan hasil studi REA pada tahun 2000 bahwa telah terjadi over eksploitasi terhadap sumberdaya ikan yang merupakan salah satu penyebab kerusakan sumberdaya di kawasan pesisir kabupaten Lombok Timur. Sementara itu, hasil studi SEA tahun 2000 menunjukkan bahwa keterampilan masyarakat pesisir Lombok Timur dalam kegiatan perikanan termasuk penangkapan ikan di lepas pantai masih kurang. Oleh karena itu, maka Cofish melakukan kegiatan silvo fisheries yaitu dengan usaha budidaya kepiting bakau (Scylla serrata) di hutan mangrove, yaitu salah satu budidaya yang dianggap mudah pelaksanaannya dan pembiayaannya murah. 


\section{b. Perbaikan lingkungan dan pusat pendaratan ikan.}

Bentuk kegiatan yang dilakukan selama 4 tahun dari tahun anggaran 2000/2001 sampai dengan 2003 dalam hal ini adalah membangun, memperluas dan merehabilitasi berbagai fasilitas untuk meningkatkan kapasitas pendaratan dan pemasaran ikan, menambah suplai air bersih untuk meningkatkan kualitas sanitasi dan higienis pengolahan ikan, menambah kapasitas docking kapal ikan, membangun rumah permanen untuk karyawan TPI dan rumah singgah nelayan, serta membangun fasilitas pendukung kegiatan perikanan dan sosial .

Secara rinci adalah sebagai berikut :

- Pembangunan docking kapal ikan di desa Tanjung Luar.

- Pembangunan kios penjualan ikan di desa Tanjung Luar.

- Rehabilitasi Pusat Pendaratan Ikan (PPI) dan Tempat Pelelangan Ikan (TPI) di desa Tanjung Luar.

- Pembangunan rumah permanen untuk staf TPI/PPI dan rumah singgah nelayan di desa Batunampar dan Tanjung luar.

- Membangun pabrik es, penanganan ikan segar, dan toilet di desa Tanjung Luar.

- Rehabilitasi Pelabuhan Ikan di Tanjung Luar.

- Pembuatan tempat pengolahan limbah ikan di desa Tanjung Luar.

- Rehabilitasi talut menahan gelombang pasang di desa Batunampar.

- Pembangunan Puskesmas Pembantu di desa Batunampar.

- Pembangunan kantor Komite Pengelolaan Perikanan laut di desa Batunampar, Tanjung Luar, dan Pijot.

- Pembangunan balai pertemuan di desa Batunampar.

- Pemasangan jaring PAM Tojong Batunampar sepanjang $25 \mathrm{Km}$, penyediaan suplai air bersih untuk $250 \mathrm{KK}$ di desa Batunampar.

- Penyediaan air bersih untuk meningkatkan kualitas sanitasi dan higienis pengolahan ikan di desa Tanjung luar.
- Penyediaan mesin pemecah es (ice tracers) sebanyak 2 buah dan 4 buah troylers, 5 buah boks ikan, 198 keranjang ikan di TPI/PPI desa Tanjung Luar.

- Penyediaan kapal patroli bagi KPPL kawasan Teluk Jukung, Teluk Ekas dan Teluk Serewe.

- Menyelenggarakan berbagai pelatihan dalam rangka meningkatkan kualitas sanitasi dan higiene TPI dan PPI.

Melihat sarana dan prasarana yang dibangun dalam program kegiatan perbaikan lingkungan dan pusat pendaratan ikan, sebenarnya sangat baik untuk menunjang kegiatan nelayan khususnya dan masyarakat desa binaan Co-fish pada umumnya. Akan tetapi, dari hasil pengamatan lapangan serta menurut informasi dari beberapa orang informan, belum semua sarana yang dibangun tersebut sudah/dapat berfungsi. Beberapa sarana yang belum berfungsi yaitu docking kapal dan tempat pengolahan limbah di desa Tanjung luar. Docking kapal tidak/belum berfungsi karena menurut informasi yang diperoleh disebabkan tidak sesuai dengan jenis-jenis kapal yang ada. Sarana lain yang tidak berfungsi adalah pemasangan pipa air minum (PAM) sepanjang $25 \mathrm{Km}$ dari Tojong Batunampar, yang sebenarnya dilakukan untuk memenuhi kebutuhan air minum masyarakat desa Batunampar, tetapi kenyataannya air tidak bisa tersalur. Menurut informasi yang diperoleh, hal itu disebabkan selain debit air yang kurang mencukupi, juga banyak pipa-pipa yang bocor. Berkaitan dengan masalah sarana air ini sebenarnya masukan dari masyarakat Desa Batunampar adalah agar dibangun beberapa sumur bor saja, karena banyak sumber air yang terdapat didesa tersebut.

\section{c. Pengembangan usaha ekonomi}

Dalam rangka pengembangan usaha ekonomi, pendekatan yang digunakan adalah pendekatan paket (pakckage), yaitu mulai dari pemberian pelatihan keterampilan usaha 
(manajerial dan penguasaan teknologi) juga pemberian kemudahan akses modal, informasi pasar untuk memudahkan pemasaran hasil, kepada KUB yang telah terbentuk.

Pelatihan penguasaan teknologi yang diberikan kepada KUB antara lain teknik budidaya, seperti budidaya ikan kerapu, lobster, rumput laut, kepiting bakau, teknik penangkapan dan pengolahan (pemindangan ikan dan pembuatan terasi udang secara higienis). Pelatihan keterampilan manajerial diberikan melalui pendampingan yang dilakukan oleh LSM yang terlibat (LP2SD). Data dari LP2SD menunjukkan bahwa pada tahun 2002 jumlah KUB yang mendapat pelatihan sebanyak 111 unit dan sepertiganya adalah wanita nelayan (pedagang/pengolah ikan) (Tim Peneliti LP2SD, 2003).

Pelatihan yang dilakukan oleh LP2SD selain terhadap usaha KUB juga terhadap LKMP (Lembaga Keuangan Masyarakat Pantai), yaitu pelatihan mengenai pengelolaan keuangan. Pelatihan ini diberikan agar pengurus/pengelola LKMP lebih profesional, serta ada keseragaman administrasi antara LKMP-LKMP yang tersebar di wilayah binaan Co-fish sehingga memudahkan dalam mengevaluasi, monitoring dan auditing.

Pemberian kemudahan akses modal, yaitu KUB memperoleh kredit dari Bank Pembangunan Rakyat (BPR), yang pengajuannya melalui LKMP. KUB yang memperoleh pinjaman dari LKMP, antara lain di Desa Sukaraja (Kecamatan Jerowaru) ada 3 (tiga) KUB dengan anggota masing-masing 20 orang pedagang ikan (kebanyakan perempuan) memperoleh kredit modal usaha sebesar Rp. 150.000,- setiap anggota ( Rp. 3.000.000,-- setiap kelompok). Pengembalian diangsur selama setahun sebesar $\mathrm{Rp}$. 320.000,- per bulan per kelompok. Di Dusun Jor, Desa Jerowaru (Kecamatan Jerowaru), KUB Satria (pengolah terasi) memperoleh kredit sebesar Rp. 5.000.000,- untuk 10 orang anggotanya (Rp. 500.000,- per anggota), dengan angsuran Rp. 60.000 sebulan selama
10 bulan.

Di samping itu, proyek Co-fish juga memberikan bantuan modal usaha berupa pinjaman dana bergulir untuk usaha budidaya ikan kerapu dengan teknik Keramba Jaring Apung (KJA) yang diberikan dalam bentuk barang (peralatan/keramba, benih dan pakan). Ada 10 KUB yang memperoleh bantuan modal usaha berupa paket KJA, yaitu 6 KUB di Dusun Batunampar, Desa Batunampar, 3 KUB di Dusun Teluk Elong, Desa Jerowaru dan 1 KUB di Dusun Ekas, Desa Pemongkong. Paket bantuan diterima dalam bentuk barang yaitu kontruksi untuk keramba, keramba, serta benih ikan kerapu, kecuali pakan yang diterima dalam bentuk uang. Satu keramba terdiri dari 4 (empat) petak yang ditebar benih masing-masing petak 200 ekor.

\section{d. Penguatan kelembagaan}

Adanya kegiatan program penguatan kelembagaan dari proyek Co-fish di desa-desa pantai di Kabupaten Lombok Timur, maka terbentuklah lembaga masyarakat yang disebut KPPL, yaitu Komite Pengelolaan Perikanan Laut di tingkat desa. Keberadaan KPPL Kawasan yang anggotanya adalah warga masyarakat yang terkait (stakeholder) dari beberapa desa disekitar kawasan, menurut informan telah dapat mengurangi konflik horizontal antar desa. Di samping itu, menurut keterangan informan, bahwa dulu sebelum ada KPPL, 40 persen ikan yang dijual di TPI Tanjung Luar dan 80 persen ikan di TPI Serewe adalah hasil penangkapan dengan bom, dan setelah ada KPPL desa dan KPPL Kawasan tersebut, penangkapan ikan dengan bom di Teluk Jukung dan Teluk Ekas sudah tidak ada, sedangkan di Teluk Serewe meskipun masih ada tetapi sudah berkurang. Mengenai komite pengelolaan perikanan laut ini, selain ditingkat desa juga dibentuk pada tingkat kabupaten, yang disebut KKPK ( Komite Kelautan Perikanan Kabupaten).

Dalam upaya peningkatan pengetahuan masyarakat yang terwakili oleh KUB, KPPL 
dan KPPK diberikan pelatihan yang berkaitan dengan pengelolaan sumberdaya perikanan laut. Materi pelatihan antara lain aspek hukum pengelolaan perikanan, pengenalan bahan atau zat terlarang bagi pemanfaatan sumberdaya laut, sistem MCS (Monitoring, Control and Surveilace), jaringan dan mekanisme operasional POKMASWAS (Kelompok Masyarakat Pengawas), jalur dan pendapatan kapal penangkap ikan, sesitem pengawasan masyarakat bidang perikanan, Galdi Posko SISWASMAS (Sistem Pengawasan Masyarakat), (YSLPP, 2003)

Penguatan kelembagaan yang berkaitan dengan pengembangan usaha ekonomi masyarakat pantai di kabupaten Lombok Timur khususnya di desa-desa pantai, dilakukan penguatan kelembagaan usaha mikro. Dalam hal ini, Co-fish telah memfasilitasi pembentukan kelompok usaha bersama (KUB) bagi rumah tangga perikanan (RTP), termasuk KUB untuk wanita nelayan. Meskipun sebenarnya, menurut keterangan beberapa orang informan, di desa-desa yang menjadi target pertama Co-fish yaitu Desa Jerowaru, Tanjung Luar, Pijot, Pemongkong, Sukaraja dan terutama di desa Batunampar, keberadaan KUB sudah lama sebelum adanya proyek Co-fish. KUB tersebut merupakan kelompok usaha baik nelayan penangkapan maupun budidaya, yaitu budidaya lobster, rumput laut maupun kepiting. Dengan adanya Co-fish, jumlah KUB menjadi bertambah. Sebagai contoh, jumlah KUB di desa Batunampar sebanyak 20 (duapuluh) KUB rumput laut, 15 (limabelas) KUB bakul ikan, 66 (enampuluh enam) KUB KJA, yaitu 6 kelompok memperoleh bantuan paket KJA sedangkan 60 kelompok adalah swadaya. Jumlah anggota kelompok KUB rumput laut masing-masing antara 7 (tujuh) sampai dengan 15 (lumabelas) orang, sedangkan KUB KJA 10 (sepuluh) orang.

Di samping itu, untuk membantu KUB dalam memperoleh kredit modal usaha, pada bulan Nopember 2001 KUB membentuk Lembaga Kuangan Masyarakat Pantai
(LKMP). Pada saat penelitian berlangsung, dii Kabupaten Lombok Timur telah terbentuk 2 (dua) LKMP yaitu LKMP Mapan mandiri di Keruak dan LKMP Mitra Bahari di Pancor. Dalam melakukan kegiatannya, LKMP memperoleh binaan dari LSM yang terlibat dalam pendampingan (Lembaga Penelitian dan Pengembangan Sumberdaya Laut/LP2SD). Pendampingan oleh LP2SD meliputi pendampingan organisasi dan pendampingan administrasi keuangan. Salah satu strategi pemberdayaan dan pendampingan terhadap LKMP adalah dengan memberikan pelatihan kepada pengurus/pengelola, yaitu dengan materi pelatihan manajemen keuangan, administrasi keuangan dan organisasi LKMP.

\subsubsection{Aturan Pengelolaan}

Menurut keterangan dari beberapa orang informan bahwa peraturan yang dibuat untuk mengatur atau melaksanakan segala sesuatu di Kabupaten Lombok Timur khususnya dan di Nusa Tenggara Barat pada umumnya disebut dengan awig-awig. Awig-awig pengelolaan kawasan teluk pada mulanya. Awig-awig yang ada adalah awig-awig desa, yaitu desa-desa yang berada di pesisir teluk, seperti misalnya desa Batunampar yang berada di pesisir Teluk Ekas, desa Tanjung Luar di pesisir Teluk Jukung. Awig-awig desa yang ada pun pada mulanya tidak secara khusus mengatur wilayah laut, tetapi mengatur tata tertib di darat dan itupun merupakan peraturan yang tidak tertulis. Akan tetapi setelah ada permasalahan di laut, yaitu konflik antar nelayan yang disebabkan oleh pengoperasian alat tangkap yang dilarang oleh masyarakat setempat, baru kemudian dibuat awig-awig yang mengatur wilayah laut dan secara tertulis. Seperti misalnya yang dikemukakan seorang informan di desa Tanjung Luar, pada tahun 1994 di kawasan Teluk Jukung khususnya yang masuk perairan Desa Tanjung Luar terjadi konflik antar nelayan tradisional (nelayan setempat) dengan nelayan purseseine (nelayan dari luar desa). Setelah 
kejadian konflik tersebut, kemudian masyarakat desa Tanjung Luar membuat awig-awig yang mengatur penggunaan alat tangkap di perairan Teluk Jukung. Akan tetapi karena perairan Teluk Jukung merupakan wilayah penangkapan dari beberapa desa yang berada di pesisirnya, maka dengan adanya proyek Co-fish, beberapa desa yang berada di pesisir teluk difasilitasi untuk bersama-sama membuat awig-awig kawasan teluk Jukung. Demikian pula desa-desa di pesisir teluk Ekas membuat awig-awig kawasan teluk Ekas dan desa-desa yang berada di pesisir teluk Serewe membuat awigawig kawasan Teluk Serewe. Hal tersebut dengan pertimbangan untuk memudahkan penanganan oleh Komite Pengelolaan Perikanan Laut (KPPL) jika ada pelanggaran yang dilakukan di kawasan teluk.

Selain awig-awig kawasan teluk tersebut juga ada awig-awig yang mengatur suaka perikanan dan kawasan konservasi. Mengenai bagaimana awig-awig tersebut dibuat atau sumber dari awig-awig tersebut, tidak berbeda dengan peraturan pengelolaan kawasan teluk, terutama untuk suaka perikanan yang berada di kawasan teluk. adalah dibuat dan disepakati bersama sama oleh masyarakat, angota dan pengurus KPPL Desa serta aparat desa dari desa-desa yang berada di sekitar suaka perikana tersebut berada. Karena suaka perikanan berada di kawasan teluk, maka selain para pengurus dan anggota KPPL Desa, ikut terlibat pula KPPL Kawasan Teluk, karena sudah terbentuk KPPL Kawasan Teluk yang melakukan pengelolaan kawasan teluk.

Sebelum peraturan/awig-awig dilaksanakan terlebih dahulu diadakan sosialisasi peraturan kepada warga masyarakat baik secara lisan maupun tertulis. Secara lisan dilakukan melalui siaran radio, pemutaran layar tancap dan pertunjukkan wayang kulit. Sementara secara tertulis dilakukan dengan menempel pengumuman di papan Co-fish yang terpasang di setiap desa binaan (desa terkait).
Dalam waktu 3 (tiga) bulan setelah peraturan ditetapkan, dengan pertimbangan bahwa sosialisasi sudah berjalan, maka peraturan tersebut mulai berlaku. Jadi, sejak saat itu, apabila terjadi pelanggaran terhadap peraturan maka pelanggar dikenakan sangsi sesuai dengan yang tertera dalam peraturan.

\subsection{Pengawasan dan Sanksi Terhadap Pelanggaran}

Pengawasan dilakukan baik secara langsung maupun tidak langsung. Pengawasan secara langsung yaitu anggota KPPL dengan sengaja mendatangi lokasi pengelolaan untuk melihat jika ada masyarakat setempat maupun orang luar yang memasuki atau melakukan kegiatan yang dilarang. Sementara pengawasan tidak langsung adalah dilakukan oleh pengawas baik anggota KPPL maupun masyarakat sambil melakukan kegiatan seperti memancing ikan di sekitar kawasan atau ketika melewati kawasan pengelolaan tersebut. Cara pengawasan yang kedua tersebut yang biasa dilakukan, karena tidak memerlukan waktu, tenaga dan biaya khusus, yang menurut pengakuan informan (baik pengurus maupun anggota $\mathrm{KPPL}$ ) terutama biaya merupakan masalah.

Meskipun Proyek Co-fish telah mengadakan sarana untuk untuk melakukan pengawasan, yaitu berupa speedboat, akan tetapi tanpa disertai oleh biaya bahan bakar. KPPL Kawasan (Teluk Jukung, Ekas dan Serewe) masing-masing juga diberi 1 (satu) unit paket KJA (keramba jaring apung) untuk budidaya ikan kerapu. Dengan sarana usaha tersebut, diharapkan hasilnya bisa untuk biaya pengawasan. Namun, menurut informasi bahwa hanya dua KJA yang berada dikawasan teluk Ekas dan Serewe yang berhasil melakukan panen pertama dan hasilnya sebagian bisa untuk membeli bibit baru intuk ditebar lagi, sedangkan di Teluk Jukung tidak berhasil. Selain itu, pada tahun 2003 setiap KPPL juga diberi usaha budidaya kepiting bakau, yang masing-masing kawasan 6 petak 
di dalam hutan bakau yang diberi pagar.

Sebenarnya harapan dari pengurus KPPL, bahwa masyarakat bisa berpartisipasi selain membantu melakukan pengawasan juga memberi bantuan dana, tetapi menurut pendapat ketua KPPL di Batunampar bahwa kesadaran masyarakat untuk itu masih kurang. Oleh karena itu, sementara ini pengawasan secara langsung terhadap kawasan pengelolaan masih mengalami kendala. Dengan adanya kendala-kendala tersebut, maka wajar bahwa masih terjadi pelanggaran. Akan tetapi, jika diperhatikan bahwa pelanggaran yang dilakukan seperti penangkapan ikan dengan bom dan potas atau penangkapan ikan lumba-lumba makin berkurang (tabel1).

Dari tabel tampak bahwa telah terjadi penurunan pelanggaran penggunaan alat dalam penangkapan ikan. Sebelum ada pengelolaan kawasan teluk, 40 persen ikan yang dijual di TPI Tanjung Luar adalah hasil penangkapan dengan bom, demikian juga di TPI Serewe bahkan mencapai 80 persen hasil penangkapan dengan bom. Pelanggar wilayah kawasan teluk, diberi sangsi sesuai dengan aturan (awig-awig) kawasan teluk, pelanggar kawasan suaka perikanan diselesaikan dengan cara yang ada dalam awig-awig suaka perikanan, demikian pula pelanggar di kawasan konservasi laut (MPA) dengan awig-awig MPA.Jika pelanggaran yang dilakukan termasuk melanggar peraturan atau undang-undang yang dibuat oleh pemerintah seperti menggunakan bom atau bahan peledak lainnya dan ditemukan buktinya, maka oleh KPPL Kawasan diajukan lagi kepada polisi untuk diproses secara hukum.

\section{Dampak Pelaksanaan Co-fish}

Pada umumnya pemerintah dalam hal ini Pemerintah Daerah Kabupaten Lombok Timur dan Kepala Desa Batunampar berpandangan bahwa program-program yang dilakukan oleh proyek Co-fish bagus dan menguntungkan, terutama dalam hal pengentasan kemiskinan masyarakat nelayan. Namun dalam tingkat pelaksanaan, berdasarkan hasil wawancara dengan beberapa informan di desa dapat

Tabel. 1. Kasus Penangkapan Ikan Menggunakan Bom dan Potas.

Tabel. 1. Cases of Fishing by Explosive and Poison.

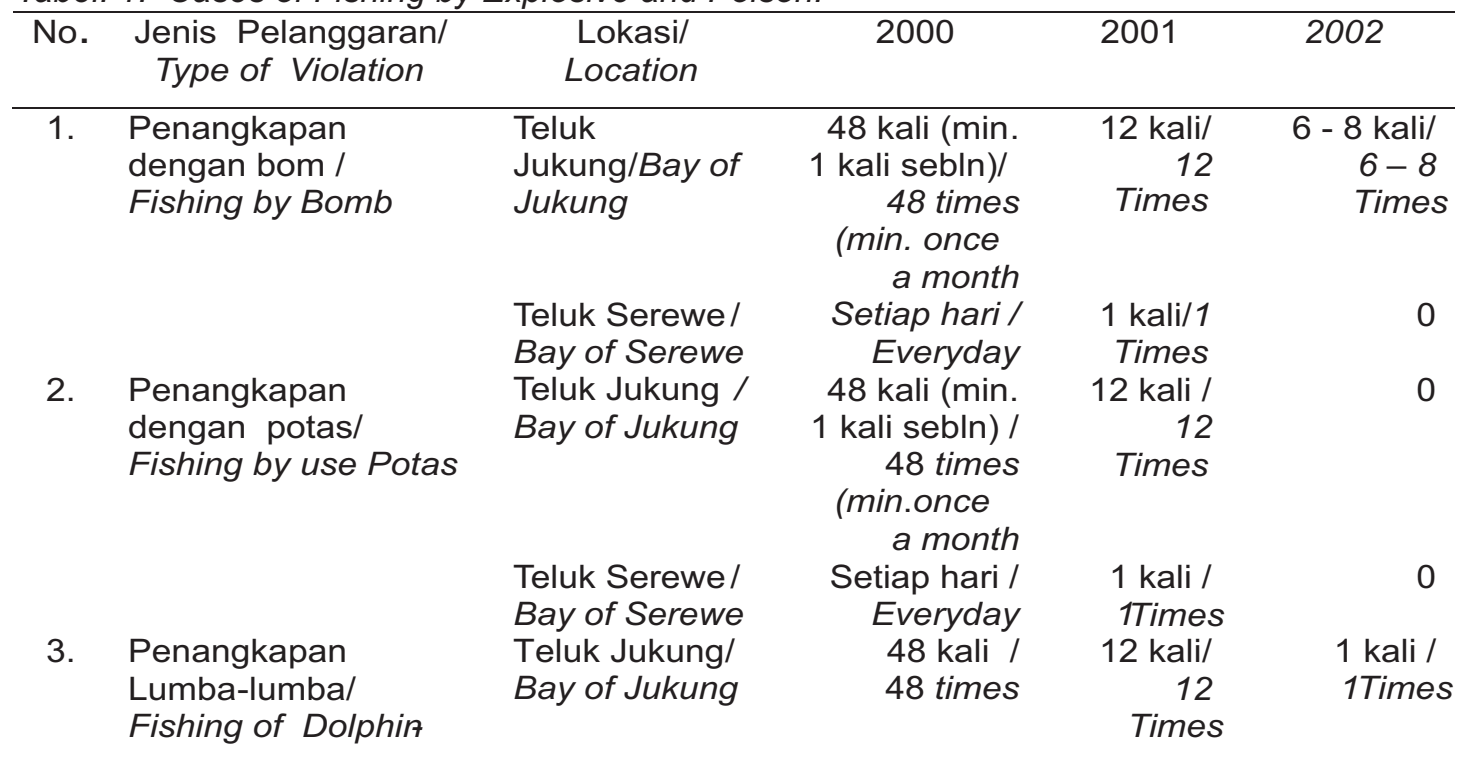

Sumber : Laporan Akhir Pendampingan LSM Dalam Rangka Pengelolaan Keanekaragaman Hayati, 2003 / Sources: The Final Report of the LSM Assistance in the Framework of Biological Iversity Management, 2003. 
diketahui bahwa kerjasama dengan daerah dan desa dirasa belum memadai dan masih kurang melibatkan peranserta aparat desa maupun masyarakat. Hal tersebut terjadi mulai dari perencanaan sampai dengan pelaksanaan, sehingga sumberdaya lokal kurang dipahami dan diperhitungkan. Akibatnya program-program di tingkat pelaksanaan sering kurang tepat sasaran. Proyek Co-fish yang melibatkan berbagai pihak tampaknya juga masih mengalami hambatan dalam hal koordinasi dan komunikasi antar berbagai pihak yang terlibat. Dampak Co-fish terhadap masyarakat nelayan dapat dilihat dari beberapa segi yaitu keadaan ekonomi nelayan, kondisi lingkungan baik lingkungan sumberdaya laut dan lingkungan pemukiman, kondisi sumberdaya manusia (SDM) nelayan serta dampak sosial.

Dari hasil pengamatan di lapangan serta hasil wawancara dengan informan kunci , bahwa adanya Co-fish cukup memberikan manfaat bagi kehidupan ekonomi nelayan di Desa Batunampar. Namun demikian, bukan berarti bahwa peningkatan ekonomi masyarakat nelayan semata-mata disebabkan oleh adanya proyek Co-fish. Seorang informan (nelayan) mengatakan bahwa kebangkitan ekonomi masyarakat nelayan Desa Batunampar terjadi sejak ada kegiatan budidaya rumput laut oleh PT Surya pada tahun 1987, yang kemudian dilakukan oleh nelayan pada umumnya. Hasil rumput laut ketika itu sangat bagus sehingga mampu meningkatkan pendapatan masyarakat. Selain budidaya rumput laut juga melakukan usaha budidaya lobster dan ikan kerapu, yang hasilnya cukup bagus pula. Apalagi pada tahun 2003 sebelum Co-fish memberikan bantuan pinjaman untuk modal usaha bagi nelayan, ada perusahaan yaitu PT Minaut yang terlebih dahulu memberikan bantuan pinjaman berupa bibit ikan kerapu dan menampung hasilnya untuk dipasarkan keluar.

Akhir tahun 2003 Co-fish baru memberikan pinjaman dana bergulir (paket
KJA), yaitu untuk kegiatan budidaya ikan kerapu dengan keramba jaring apung (KJA). Namun dalam hal ini, tampaknya belum membuahkan hasil, karena di samping belum lama turunnya bantuan tersebut, dan turunnyapun tersendat-sendat, juga bibit yang diberikan tidak sesuai dengan yang diharapkan. Sebagai contoh bahwa dalam pelatihan diberikan cara-cara budidaya ikan kerapu bebek, tetapi ketika bantuan turun, bibit yang diberikan ikan kerapu macan. Kedua jenis ikan tersebut memiliki perlakukan yang berbeda, lebih sulit membudidayakan ikan kerapu macan karena sifatnya yang kanibal, sementara dalam kegiatannya tidak ada pendampingan. Oleh karena itu, beberapa informan yang menjadi anggota kelompok (KUB) yang memperoleh bantuan paket KJA tersebut mengatakan bahwa sebenarnya proyek Co-fish sangat baik dan mereka mendukung, akan tetapi mereka merasa tersita waktunya untuk mengelola bibit ikan kerapu macan tersebut. Apalagi dengan terlambat turunnya dana pakan hingga 5 bulan setelah bibit diberikan, sehingga mereka harus mengupayakan pakan sendiri dengan keterbatasan dana mereka. Dengan demikian hasil yang diperoleh tidak maksimal, bahkan belum ada, karena banyak ikan yang mati dimakan oleh sesamanya. Meskipun demikian, ada pula kelompok usaha yang berhasil meningkatkan usahanya setelah memperoleh binaan dari Co-fish, yaitu yang dialami KUB terasi di Dusun Jor, desa Jerowaru.

Peningkatan kesejahteraan masyarakat juga dapat diketahui dari kondisi perumahan atau tempat tinggal mereka. Berdasarkan pengamatan serta keterangan yang diperoleh dari informan bahwa pada umumnya rumahrumah di Desa Batunampar berbentuk rumah panggung dan sebagian besar milik sendiri. Akan tetapi, rumah penduduk tersebut tidak memiliki sarana untuk mandi, mencuci dan kakus (MCK). Sebenarnya dalam beberapa tahun sejak adanya proyek Co-fish tidak ada peningkatan yang menonjol dari segi 
perumahan kecuali dari segi penerangan karena masuknya listrik di desa tersebut.

Dampak Co-fish terhadap kondisi lingkungan sumberdaya laut, berdasarkan keterangan yang diperoleh dari beberapa orang informan, cukup positif yaitu terjadi penurunan tingkat penggunaan bom dan potasium untuk menangkap ikan. Hal ini dikarenakan adanya pengelolaan sumberdaya perikanan yang diadakan oleh Co-fish yang meliputi pengelolaan kawasan teluk (Teluk Ekas, Jukung dan Serewe), pengelolaan Suaka Perikanan di kawasan Teluk tersebut serta dibentuknya pengelolaan kawasan konservasi laut (MPA). Selain itu, juga adanya peraturan yang mengatur kegiatan apa saja yang boleh dilakukan dan dilarang dilakukan serta sangsi yang dikenakan terhadap pelanggar peraturan tersebut. Peraturan tersebut yang biasa disebut awig-awig pengelolaan sumberdaya perikanan, yaitu Awig-awig Pengeloaan Kawasan Teluk, Awig-awig Pengelolaan Suaka Perikanan serta Awig-awig Pengelolaan Kawasan Konservasi Laut.

Dengan adanya penurunan penggunaan bom, maka lingkungan ekosistem yang merupakan habitat ikan menjadi baik, sehingga keberadaan ikan menjadi bertambah atau stok ikan semakin meningkat. Stok ikan yang meningkat mengakibatkan tingkat produksi nelayan meningkat sehingga pendapatan nelayan meningkat pula.

Namun demikian, meskipun produksi tangkapan nelayan banyak, kegiatan pemasaran ikan di PPI/TPI Desa Batunampar tidak meningkat secara signifikan, padahal telah dibangun 2 (dua) lokal fasilitas PPI/TPI. Dengan kata lain bahwa dibangunnya fasilitas tersebut kurang bermanfaat, karena kurang didukung sarana infrastruktur lain, seperti jalan menuju tempat tersebut kondisinya yang sudah rusak, selain itu juga nelayan lebih senang mendaratkan hasil tangkapannya di TPI Tanjung Luar yang memiliki akses pasar lebih luas sehingga harga ikan lebih baik.
Dari segi sanitasi lingkungan belum terlihat pengaruhnya, masih banyak masyarakat nelayan yang membuang kotoran di laut, ditambah lagi masih banyak rumah tangga yang tidak mempunyai MCK sendiri sehingga biasanya mereka membuang hajat ke laut. Apalagi adanya program air bersih yang dilakukan oleh Co-fish bekerjasama dengan PDAM, yaitu pemasangan pipa ke Desa Batunampar belum juga tuntas bahkan air belum juga mengalir sampai ke pemukiman nelayan di Dusun Batunampar. Hingga saat ini penduduk Desa Batunampar berharap terealisasinya program air bersih tersebut. Selain itu, fasilitas lain yang telah dibangun tetapi kurang bermanfaat adalah Balai Pertemuan dan toilet karena sarana airnya tidak ada.

Dampak yang cukup menonjol adalah dengan dibangunnya gedung Puskesmas Pembantu yang sangat bermanfaat bagi penduduk yaitu tidak hanya sebagai pelayanan berobat, tetapi mengubah perilaku berobat dari dukun ke Puskesmas. Kemajuan lain adalah terjadi penurunan angka penduduk yang sakit terutama penyakit malaria, ISPA dan penyakit kulit.

Selanjutnya mengenai kondisi SDM nelayan, tampaknya masih tetap dalam keterbatasan, walaupun telah ada program pelatihan bagi nelayan maupun pengolah ikan yang diadakan oleh Co-fish seperti teknik dan manajerial dalam menangani ikan segar dan ikan olahan (pengawetan ikan dan pembuatan abon ikan), bahkan pelatihan dan penyuluhan tentang sanitasi/kesehatan lingkungan. Hal ini disebabkan kurangnya partisipasi dalam program pelatihan dan pendampingan yang dilakukan oleh LSM yang terlibat dalam program Co-fish. Masyarakat yang mengikuti pelatihan sangat terbatas jumlahnya. Dalam menentukan peserta tersebut, tampaknya tidak dimusyawarahkan bersama Kepala Desa atau Kepala Dusun. Meskipun beberapa kali diadakan pelatihan tetapi pesertanya adalah orang tertentu saja yang 
mengikuti secara berulang-ulang. Walaupun cukup banyak peserta baru dalam pelatihan yang kebanyakan adalah perempuan (yang terlibat dalam KUB) yaitu dalam kegiatan perdagangan dan pengolahan ikan, tetapi masih dalam taraf sosialisasi. Disamping itu, materi pelatihan yang diberikan juga kemungkinan kurang dapat dimengerti, karena dilihat dari bahan materi pelatihan yang ada tampaknya yang kurang sesuai dengan tingkat pendidikan dari masyarakat yang ikut dalam pelatihan yang rata-rata masih rendah. Mengenai program pelatihan dan pendampingan untuk pengembangan KUB yang dilakukan oleh LSM hanya dalam waktu beberapa hari/minggu, dan pendampingan oleh LKMP hanya selama memanfaatkan kredit yang diberikan (selama setahun).

Mengenai dampak sosial dari adanya Cofish, terlihat adanya peningkatan dalam hal koordinasi antar institusi teknis terkait dan kemampuan staf dalam pengelolaan sumberdaya perikanan. Namun disisi lain terdapat kecenderungan yang mendua antara kegiatan proyek dengan kegiatan rutin oleh institusi yang ada di Dinas Kelautan dan Perikanan. Bila ini tidak dibenahi akan terjadi tumpang tindih kebijakan dalam pengelolaan SDPP dan dapat menghambat optimalisasi pemanfaatan dan konservasi SDPP.

Dalam hal kelembagaan, nampaknya yang meningkat adalah kelembagaan perempuan, walaupun hanya sebagian kecil perempuan yang terlibat dalam lembaga usaha (KUB) dan lembaga sosial, dan bahkan tidak ada yang duduk dalam keanggotaan KPPL Namun demikian, perkembangan perempuan yang terlibat dalam kegiatan tataniaga ikan, yaitu sebagai pedagang ikan segar dan pengolah ikan cukup banyak, yaitu dengan dibentuknya KUB perdagangan dan pengolahan ikan dan diberi pelatihan serta pendampingan oleh LSM.

\section{B. Pembahasan}

Pengelolaan Sumberdaya Perikanan Pantai di Lombok Timur melalui Proyek Cofish telah dilakukan dengan pendekatan comanagement. Hal tersebut tampak dari caracara yang dilakukan dengan melibatkan berbagai stakeholder terkait, seperti masyarakat yang terdiri dari nelayan pedagang, pengolah hasil laut, lembaga masyarakat (LSM, KUD) serta kalangan akademisi (perguruan tinggi). Namun demikian, selain memiliki kekuatan dalam arti ada keberhasilan, akan tetapi tampaknya masih memiliki kelemahan.

Bahwa keberhasilan co-management menurut Polnac yang dikutip oleh Pomeroy, Katon dan Harkes (2001 :199) adalah dipengaruhi oleh beberapa faktor yang dikelompokkan dalam tiga tingkatan yaitu tingkat supra komunitas (supra community level), tingkat komunitas (community level) dan tingkat individu dan rumah tangga (individual and houshold level).

Pada tingkat supra komunitas, faktor utama keberhasilan co-management adalah adanya dukungan pemerintah yang diwujudkan dalam bentuk kebijakan atau peraturan perundang-undangan. Hasil penelitian menunjukkan bahwa pemerintah baik tingkat pusat (Departemen Kelautan dan Perikanan) maupun daerah Dinas kelautan dan Perikanan telah memberikan dukungan dalam pengelolaan sumberdaya laut, baik dalam bentuk kebijakan dan peraturan maupun dana. Meskipun peraturan yang ada bukan semata-mata dikeluarkan dalam rangka program Co-fish, karena peraturan tersebut sudah ada sebelum adanya program tersebut. Beberapa peraturan perundangan yang erat kaitannya dengan pengelolaan sumberdaya perikanan, antara lain adanya Undangundang Nomor 5 tahun 1983, Peraturan Pemerintah Nomor 15 Tahun 1984, Undangundang Nomor 9 Tahun 1985, dan Undangundang Nomor 23 tahun 1997.

Secara konkrit seperti adanya pasal dalam peraturan pemerintah mengenai larangan penangkapan menggunakan bom dan bahan beracun. Dengan banyaknya penggunaan bom dan racun oleh nelayan 
untuk menangkap ikan di perairan Kabupaten Lombok Timur, maka adanya peraturan tersebut sangat membantu masyarakat dalam melakukan pengelolaan sumberdaya perikanan di wilayah tersebut.

Dalam rangka menjalankan proyek Cofish, pemerintah juga membuat peraturan yang mengatur kinerja pemerintah dari pemerintah Pusat sampai dengan pemerintah Daerah (Propinsi dan Kabupaten). Pada tingkat daerah, pemerintah daerah Tk I Propinsi Nusa Tenggara Barat juga telah mengeluarkan peraturan mengenai usaha perikanan (Perda No 9 tahun 1995), pemerintah daerah Tk I Kabupaten Lombok Timur mengeluarkan peraturan tentang retribusi ijin usaha perikanan (perda No 18 Tahun 2002). Sementara yang langsung berkaitan dengan program kegiatan Co-fish, Bupati dan Kepala Dinas Kelautan dan Perikanan juga telah mengeluarkan Keputusan tentang Pengukuhan Keberadaan Komite Kelautan Perikanan Kabupaten (KKPK) dan Komite Pengelolaan Perikanan Laut (KPPL).

Selain peraturan, dukungan dalam bentuk pembinaan juga dilakukan oleh Dinas Kelautan dan Perikanan Kabupaten Lombok Timur, yaitu teknik pembinaan penangkapan dan budidaya, pembinaan usaha tani nelayan serta pembinaan pengawasan dan perlindungan laut. Sementara dukungan dalam bentuk dana oleh pemerintah, yaitu adanya dana ADB dan APBN untuk pelaksanaan proyek Co-fish tersebut. Meskipun sebenarnya masih ada kecenderungan yang mendua antara kegiatan proyek dengan kegiatan rutin oleh institusi yang ada di pemerintahan pusat.

Dukungan pemerintah lainnya yang terkait dengan pengelolaan wilayah laut terlihat dengan dibentuknya KKPK (Komite Kelautan dan Perikanan Kabupaten) tersebut yang berfungsi sebagai wakil masyarakat pantai dan instansi Pemerintah dalam merumuskan penyelesaian masalah-masalah pengelolaan sumberdaya perikanan.
Sementara dukungan pemerintah pada level bawah, yaitu pemerintahan lokal (desa) masih belum optimal. Keterlibatan pemerintahan desa hanya pada awal kegiatan Co-fish (pada perencanaan), tetapi berkurang saat pelaksanaannya. Akan tetapi dalam hal ini, menurut pengakuan informan kunci bahwa kurang terlibatnya mereka dalam pelaksanaan kegiatan bukan karena tidak bersedia, akan tetapi disebabkan mereka tidak dilibatkan lagi. Disamping itu tampaknya dari keterangan yang diperoleh, bahwa ada masukan-masukan dari pemerintah level bawah dan masyarakat yang tidak dijadikan pertimbangan dalam pelaksanaan kegiatan. Salah satu contoh adalah adanya program air bersih di Desa Batunampar, yaitu hasil kerjasama Co-fish dengan PDAM, yang meskipun sudah selesai kegiatannya namun belum bisa dimanfaatkan oleh masyarakat Desa Batunampar. Menurut informan, hal tersebut disebabkan antara lain karena pelaksanaan kegiatan tersebut tidak memperhitungkan sumberdaya manusia lokal, padahal hal itu telah disampaikan dalam forum rapat yang membahas perencanaan program.

Selain dukungan pemerintah untuk keberhasilan co-management diperlukan juga dukungan dari tenaga pendamping (external agent). Kegiatan proyek Co-fish di Kabupaten Lombok Timur memang melibatkan beberapa tenaga pendamping, baik dari agen pemerintah maupun LSM, yaitu LSM yang berada di kota propinsi (Mataram) maupun di kota kabupaten ( Selong). Namun, karena pendampingan yang dilakukan hanya dalam waktu yang relarif singkat, yang menurut pengakuan salah satu LSM yang dilibatkan sebagai tenaga pendamping hanya sebatas jangka waktu proyek (antara 3 - 5 bulan) saja, maka menjadi kurang efektif dan hasilnya tidak maksimal. Dengan singkatnya waktu p e n d a m p i n g a n, s e m e n t a r a pembinaan/pelatihan yang diberikan dalam pendampingan merupakan hal atau pengetahuan baru bagi KUB seperti misalnya mengenai manajemen usaha, pembukuan 
yang tidak mudah untuk mereka pahami, maka begitu selesai pendampingan, kegiatan-kegiatan yang diberikan dalam pendampingan tidak diterapkan lagi oleh masyarakat (KUB). Contoh konkrit yang menggambarkan kurangnya pendampingan sehingga menyebabkan ketidak berhasilan kegiatan adalah berkaitan dengan pembinaan/pelatihan budidaya ikan kerapu kepada KUB yang dibentuk oleh Co-fish di Desa Batunampar. Sebagaimana telah dikemukakan bahwa Co-fish dalam salah satu kegiatannya yaitu penguatan usaha mikro telah memberikan pelatihan teknik budidaya ikan kerapu bebek kepada 6 (enam) KUB yang dibentuk, yang sebenarnya telah menguasai pula teknik tersebut. Setelah memperoleh pelatihan KUB tersebut diberi paket bantuan Keramba Jaring Apung (KJA) untuk budidaya ikan kerapu. Jenis ikan kerapu yang kemudian diberikan dalam paket bantuan kepada KUB berbeda dengan jenis yang disampaikan dan disepakati dalam pelatihan (dalam pelatihan diajarkan cara budidaya kerapu bebek sedangkan kenyataannya bibit yang diberikan kerapu macan yang memiliki sifat berbeda). Sementara itu, dalam melakukan budidaya kerapu macan, Co-fish tidak menyediakan tenaga pendamping yang bisa membantu KUB jika ada masalah dengan teknik pemeliharaan kerapu macan tersebut. Akhirnya hampir semua kelompok yang memperoleh bantuan paket KJA ikan kerapu melalui beberapa anggotanya ketika diwawancarai menyatakan kesulitan dalam menjalankan usaha budidaya kerapu macan tersebut dan menurut mereka banyak ikan yang mati sebelum menjadi besar.

Pada tingkat Masyarakat (Community Level), keberhasilan co-management sangat terkait dengan tiga hal, yaitu: wilayah pengelolaan, lembaga pengelola dan tingkat pengelolaan. Berkaitan dengan wilayah pengelolaan, yang perlu diperhatikan adalah lokasi wilayah yang dikelola dan kejelasan wilayah pengelolaan, baik batas-batasnya secara fisik, maupun jenis sumberdaya dan ekosistem yang ada di dalamnya. Selain itu juga siapa yang memiliki hak untuk memanfaatkan wilayah itu. Berkaitan dengan itu, alat tangkap apa yang boleh digunakan di wilayah itu merupakan faktor lain yang penting. Semua itu terkait dengan satu permasalahan utama, yaitu bagaimana agar kelestarian sumberdaya di wilayah itu dapat terjamin. Terkait dengan wilayah pengelolaan itu adalah luasnya wilayah yang dikelola, yang disarankan agar tidak terlalu luas.

Dilihat dari wilayah pengelolaan Co-fish di Kabupaten Lombok Timur memang luas, tetapi terbagi-bagi dalam kawasan-kawasan seperti kawasan teluk, kawasan suaka perikanan (SP), kawasan konsevasi laut (MPA), yang masing-masing memiliki batas wilayah yang jelas baik secara fisik maupun sumberdaya yang ada di dalamnya. Adanya batas wilayah yang jelas tersebut serta didukung oleh adanya aturan-aturan pengelolaan wilayah seperti kegiatan apa saja yang boleh dan tidak boleh dilakukan dalam wilayah tersebut, jenis alat tangkap yang boleh dan tidak boleh digunakan serta sumberdaya yang boleh dan tidak boleh dieksploitasi serta sanksi terhadap pelanggarannya. Selain itu juga ada pengawasan yang dilakukan baik oleh lembaga masyarakat (KPPL) maupun masyarakat umum. Berkaitan dengan wilayah pengelolaan tampaknya tidak terlalu sulit bagi masyarakat dalam mengelolanya, dan terdapat hasil yang cukup baik dalam pengelolaan wilayah dan sumberdaya perikanan yang ada. Sebagai gambaran adalah terjadinya penurunan tingkat penggunaan bom dan potasium untuk menangkap ikan oleh warga masyarakat yang memiliki kepedulian dalam kelangsungan sumberdaya, terutama di kawasan Teluk Ekas dan Jukung. Hal itu, tidak lepas dari dukungan masyarakat yaitu dengan cara mentaati peraturan (awig-awig) yang telah disepakati bersama.

Berkaitan dengan lembaga pengelola, penjelasan yang dikemukakan oleh Pomeroy 
dkk (2001) bahwa jumlah orang yang terlibat ddidalamnya merupakan hal yang penting, semakin banyak yang terlibat maka proses pengambilan kebijakan pengelolaan semakin sulit. Dalam kaitannya dengan hal tersebut, bahwa lembaga pengelolaan yang ada di tiaptiap kawasan pengelolaan, yang pembentukannya difasilitasi oleh Co-fish yaitu KPPL memiliki jumlah anggota dan pengurus sebanyak 16 (enambelas) orang, dan KKPK beranggotakan 23 (duapuluh tiga) orang. Dengan melihat wilayah pengelolaan pada target pertama yaitu 6 (enam) desa, maka jumlah anggota pengurus KKPK dapat dikatakan cukup, dan tidak terlalu banyak, demikian pula jumlah anggota KPPL kawasan yang sebanyak 16 orang tersebut. Akan tetapi masalahnya adalah bahwa anggota dan pengurus dari lembaga tersebut belum mewakili stakeholder yang terlibat dalam pengelolaan sumberdaya laut di kawasan tersebut.

Padahal dalam penjelasan Pomeray bahwa keterwakilan (representasi) stakeholder itu diperlukan, karena diasumsikan setiap kelompok stakeholder memiliki kepentingan yang berbeda, yang mungkin berbenturan antara satu dengan yang lain. Dengan terwakilinya setiap unsur yang ada dalam kelompok stakeholder, berbagai kepentingan itu diharapkan bisa terwakili. Dengan demikian di dalam comanagement, diperlukan adanya kerelaan dari semua pihak untuk mengorbankan sebagian kepentingannya, untuk mendukung kepentingan bersama.

Adanya keterwakilan dari kelompok stakeholder, diharapkan agar keterpaduan dalam pengelolaan dapat dilakukan. Karena itu keterpaduan yang dituntut dalam comanagement bukan hanya keterpaduan antar suatu lembaga pemerintah tertentu dengan beberapa wakil dari masyarakat, karena keterpaduan yang demikian adalah keterpaduan semu. Dalam co-management, keterpaduan yang demikian tidak akan mencapai hasil yang memuaskan, karena bisa saja kesepakatan yang dihasilkan tidak mewadahi kepentingan dari unsur-unsur yang lain. Keterpaduan yang dituntut dalam comanagement adalah keterpaduan dalam arti yang sebenarnya, yaitu yang dapat mewadahi kepentingan semua pihak, termasuk unsurunsur yang terdapat di pemerintahan, masyarakat dan unsur-unsur di dalam industri itu sendiri.

Hernes dan Sandersen (tt: 2) melihat bahwa representasi dari setiap unsur yang ada di setiap kelompok stakeholder itu merupakan suatu problem serius yang harus dihadapi dalam co-management. Hal ini karena dalam realitasnya stakeholder itu tidak homogen. Di masyarakat misalnya, walaupun dalam perspektif yang terbatas masyarakat nelayan bisa diartikan sebagai orang-orang yang kehidupannya tergantung langsung pada hasil laut, namun nelayan itu sendiri tidak tunggal, karena di dalamnya terdapat perbedaan teknologi yang digunakan, baik jenis maupun daya eksploitasinya, perbedaan jenis sumberdaya yang ditangkap, perbedaan etnis, dan berbagai perbedaan yang lain. Selain itu, masyarakat yang kehidupannya tergantung pada hasil laut juga bukan hanya mereka yang langsung mengeksploitasi sumberdaya laut, melainkan juga mereka yang secara tidak langsung memperoleh manfaat dari pengelolaan lingkungan laut. Dengan demikian yang disebut masyarakat juga meliputi pihak-pihak lain yang berkepentingan terhadap kelestarian lingkungan laut, seperti pedagang hasil laut.

Karena keterwakilan stakeholder itu sangat diperlukan, maka semakin kurang heterogen masyarakatnya, akan semakin mudah co-management itu dilakukan, karena tenaga yang terlibat dalam pengelolaan lebih sedikit. Karena itu, jika heterogenitas masyarakatnya sangat tinggi, sehingga dengan keterwakilan para stakeholder maka jumlah orang yang terlibat dalam lembaga pengelola cukup banyak, maka disarankan untuk membagi mereka ke dalam kelompokkelompok yang lebih kecil (Pomeray et al, 
2001). Dengan demikian proses pengambilan keputusan dalam kelompok lebih mudah dilakukan. Meskipun demikian, koordinasi antara kelompok-kelompok pengelola yang kecil itu perlu dilakukan, untuk mengintegrasikan kepentingan yang lebih besar, yaitu kelestarian sumberdaya. Inilah yang oleh Pomeroy dkk disebut tingkat pengelolaan.

Berkaitan dengan lembaga pengelola tersebut, beberapa hal yang menurut Pomeroy dkk perlu diperhatikan, yang secara ringkas meliputi: (1) keanggotaan yang jelas, (2) homogenitas kelompok, (3) partisipasi anggota, (4) kepemimpinan, (5) sumber dana yang mencukupi, (6) transparansi dan akuntabilitas, dan (7) dan manajemen konflik. Selain itu adalah pemberdayaan anggota dan pembangunan kapasitas kelembagaan

Bahwa stakeholder dalam pengelolaan sumberdaya laut antara lain adalah pemerintah, masyarakat yang terdiri dari pengusaha pengolah hasil laut, nelayan (pemilik dan buruh nelayan dari berbagai jenis alat tangkap), pedagang, LSM serta kalangan akademisi (perguruan tinggi). Kenyataannya bahwa lembaga pengelola yang ada, keanggotaannya tidak mewakili seluruh stakeholder terkait seperti di atas. Seperti telah disebutkan di bab terdahulu bahwa lembaga pengelolaan sumberdaya perikanan di Kabupaten Lombok Timur adalah KKPK dan KPPL. KKPK (Komite Kelautan Perikanan Kabupaten) merupakan lembaga pengelola yang ada di tingkat kabupaten, anggotanya hanya dari unsur pemerintah dan masyarakat. Meskipun dari unsur masyarakat yang merupakan wakil dari beberapa kawasan, tetapi tampaknya belum bisa dianggap telah mewakili setiap unsur dari stakeholder masyarakat, seperti dari unsur nelayan tidak tampak adanya keterwakilan dari berbagai jenis alat tangkap. Kemudian dilihat dari jumlahnya, dari pengusaha hanya 1 (satu) orang, pedagang hanya 1 (satu) orang. Apalagi jika dilihat keterwakilan secara gender tampak tidak bisa dianggap imbang karena hanya ada 1 (satu) orang wanita yang duduk dalam kepengurusan/keanggotaan KKPK, yaitu sebagai wakil dari wanita nelayan (pedagang ikan). Di samping itu tidak tampak adanya wakil dari LSM. Padahal representasi (keterwakilan) stakeholder menurut Harnes dan Sanderson (tt: 2) merupakan problem serius dalam co-management, sehingga. sangat penting diperhatikan untuk keberhasilan dalam pengelolaan, karena setiap kelompok stakeholder memiliki kepentingan berbeda yang kemungkinan bisa berbenturan antara satu dengan lainnya.

Sementara, mengenai keanggotaan KPPL yang merupakan lembaga pengelola yang ada di tingkat kawasan (KPPL Kawasan), meskipun menurut keterangan dari salah seorang ketua KPPL kawasan, sudah melibatkan berbagai unsur stakeholder, tetapi kenyataannya unsur stakeholder nelayan belum mewakili nelayan dari berbagai jenis alat tangkap. Selain itu juga tidak ada wakil dari kelompok perempuan, yang duduk dalam KPPL, padahal kebanyakan pedagang/pengolah ikan adalah kaum perempuan.

Dengan demikian, dilihat dari keanggotaan lembaga pengelola tampaknya masih terdapat kelemahan, yaitu belum bisa dianggap mewakili seluruh unsur stakeholder yang ada. Lebih-lebih lagi, bahwa pemilihan anggota pengelolapun tidak dilakukan secara terbuka, yaitu berdasarkan musyawarah bersama masyarakat secara luas. Pemilihan anggota KPPL ditentukan berdasarkan orang yang dikenal dan yang biasa terlibat dalam kegiatan yang dilakukan oleh Dinas Kelautan dan Perikanan.

Selain tiga faktor utama yang mendukung keberhasilan co-management, Pollnac, sebagaimana dikutip oleh Pomeray dkk (Pomeray et al, 2001) juga menyebutkan beberapa hal lain di masyarakat yang ikut menunjang bagi keberhasilan comanagement, yaitu: (1) partisipasi masyarakat, (2) dukungan organisasi masyarakat yang ada, (3) dukungan jangka 
panjang dari unit pemerintahan lokal (desa), (4) hak-hak properti atas sumber daya, dan (5) rasa memiliki terhadap proses comanagement.

Apabila dilihat dari partisipasi anggota, maka tampaknya ada kelemahan, karena menurut pengakuan salah seorang anggota KPPL, bahwa anggota KPPL tidak melakukan tugasnya (pengawasan) terhadap pengelolaan sumberdaya laut yang diterapkan di kawasannya secara rutin. Alasan mereka karena terbentur masalah dana operasional untuk melakukan pengawasan, yang sebenarnya bisa diusahakan melalui swadaya anggota dan masyarakat. Dalam hal ini tampak bahwa partisipasi anggota maupun masyarakat kurang.

Tampaknya, masalah dana memang merupakan kendala utama dalam melaksanakan pengawasan. Karena Co-fish memang tidak menyediakan dana secara langsung untuk memenuhi kebutuhan biaya operasional untuk itu. Co-fish hanya memberikan sarana berupa Speetboat tanpa dana untuk biaya bahan bakarnya, itupun tidak merata untuk seluruh lokasi pengelolaan, tetapi hanya di tiga lokasi, yaitu untuk pengelolaan di kawasan teluk Ekas, Jukung dan teluk Serewe. Memang Co-fish juga memberikan paket bantuan untuk budidaya ikan kerapu (paket KJA) bagi masing-masing KPPL, dengan tujuan agar hasil budidaya tersebut dapat membiayai kebutuhan dalam melakukan pengawasan. Namun demikian, menurut informasi yang diperoleh bahwa usaha budidaya tersebut belum memberikan hasil, bahkan ada yang tidak dilanjutkan usahanya karena mengalami kegagalan (bibit ikan banyak yang mati).

Dengan kurang diperhatikannya masalah partisipasi anggota serta kurangnya dukungan dana untuk pelaksanaan kegiatan oleh proyek Co-fish, menyebabkan keberhasilan comanagement yang diterapkan oleh Co-fish belum optimal. Meskipun telah terjadi penurunan penggunaan bom dan potasium untuk menangkap ikan di kawasan teluk yang sebelumnya sering terjadi, tetapi penurunan itu terutama di kawasan teluk yang dekat dengan pemukiman (Teluk Ekas dan Jukung), sedangkan di Teluk Serewe yang lokasinya jauh dari pemukiman masih banyak terjadi, karena sulit bagi KPPL dan masyarakat dalam melakukan pengawasan, kalau tidak disertai dana yang cukup atau partisipasi yang tinggi dari mereka.

Di samping faktor-faktor tersebut, dikemukakan oleh Pomeray dkk (2001) faktor ketiga yang mempengaruhi tingkat keberhasilan co-management yaitu tingkat individu dan rumah tangga. Yang dimaksudkan bahwa co-management akan dikatakan berhasil apabila individu dan rumah tangga dapat merasakan dampak atau manfaat dari pengelolaan co-management tersebut. Jika sebagian besar user merasa mendapatkan keuntungan dari praktik comanagement yang sedang berjalan, maka prospek keberhasilan co-management akan lebih besar. Sebaliknya, jika sebagian besar user merasa dirugikan oleh praktik comanagement yang dilaksanakan, maka kegagalan akan menghadang. Karena itu secara tidak langsung keinginan individu atau kepala keluarga memiliki pengaruh yang besar dalam menentukan bentuk dan arah comanagement yang jalankan.

Berkaitan dengan hal itu, maka dampak adanya kegiatan Co-fish dilihat dari tingkat kesejahteraan masyarakat dapat dikatakan telah terjadi peningkatan. Namun demikian, peningkatan kesejahteraan masyarakat tersebut tampaknya tidak semata-mata merupakan dampak dari kegiatan Co-fish. Karena kegiatan Co-fish yang langsung berkaitan dengan usaha ekonomi belum lama dilakukan. Seperti program paket bantuan Keramba Jaring Apung (KJA) untuk budidaya ikan kerapu, yang baru terealisir akhir tahun 2003, itupun berjalan tersendat, karena paket bantuan tidak diturunkan sekaligus. Selain itu, juga bibit ikan kerapu yang termasuk dalam paket tidak sesuai dengan jenis yang diinginkan/diusulkan KUB yang memperoleh 
bantuan dan diajarkan dalam pelatihan sebelumnya. Dengan tersendatnya bantuan paket KJA tersebut serta tidak sesuai dengan masukan dari anggota KUB yang disampaikan saat pelatihan, menyebabkan ketidak berhasilan program tersebut.

Apabila banyak masyarakat yang melakukan usaha budidaya ikan kerapu dengan sistem KJA, itu karena memang telah mereka lakukan sebelumnya. Di samping itu, sebelumnya juga telah ada pihak lain yang memberikan bantuan paket seperti yang Cofish berikan. Sehingga apabila kesejahteraan masyarakat desa-desa binaan Co-fish mengalami peningkatan, seperti terlihat dari peningkatan kondisi tempat tinggal, itu bukan semata-mata dampak dari proyek Co-fish, dan itu diakui oleh beberapa informan dalam penelitian ini.

Namun demikian bukan berarti bahwa masyarakat sama sekali tidak merasakan manfaat kegiatan yang dilakukan oleh Co-fish. Hasil kegiatan Co-fish yang sangat dirasakan manfaatnya oleh masyarakat khususnya masyarakat Desa Batunampar adalah dengan dibangunnya sebuah gedung Puskesmas Pembantu. Dengan adanya fasilitas kesehatan tersebut, memudahkan masyarakat untuk berobat, sehingga tidak lagi harus pergi ke Puskesmas Praya (salah satu kota kecamatan di Kabupaten Lombok Tengah), yaitu tempat berobat yang terdekat untuk dicapai dari Desa batunampar. Disamping itu dari segi prasarana perbaikan lingkungan adalah dengan dibangunnya Talut gelombang disepanjang pinggir pantai di Dusun Batunampar, sehingga dapat menghalangi gelombang air laut agar tidak menjangkau pemukiman. Fasilitas lain yang cukup bermanfaat adalah dibangunnya tempat pengolahan ikan di dekat lokasi pendaratan ikan di Batunampar, meskipun fasilitas itu banyak dimanfaatkan oleh masyarakat desa lain yang biasa datang untuk membeli ikan di Batunampar dan sekaligus mengolahnya (mengasap).

\section{KESIMPULAN DAN IMPLIKASI KEBIJAKAN}

\section{Kesimpulan}

Praktik pengelolaan lingkungan pantai yang dilaksanakan oleh Co-fish merupakan suatu pendekatan baru, yang perlu dilakukan di daerah-daerah yang lain. Pembentukan kelompok stakeholder untuk dilibatkan dalam pengelolaan lingkungan pantai dan pelestarian sumberdaya perikanan merupakan upaya yang positif, dalam membantu pemerintah untuk mengelola lingkungan. Namun demikian, meskipun dalam melaksanakan proyek Co-fish di Kabupaten Lombok Timur telah berusaha menggunakan pendekatan co-management, yang pada saat ini masih merupakan pendekatan pengelolaan yang dianggap ideal, tetapi tampaknya aturan-aturan comanagement yang ada belum dilaksanakan sepenuhnya, sehingga belum bisa memperoleh hasil yang optimal.

\section{Implikasi Kebijakan}

Praktik pengelolaan lingkungan pantai yang dilaksanakan oleh Co-fish merupakan suatu pendekatan baru, yang perlu dilakukan di daerah-daerah yang lain. Pembentukan kelompok stakeholder untuk dilibatkan dalam pengelolaan lingkungan pantai dan pelestarian sumberdaya perikanan merupakan upaya yang positif, dalam membantu pemerintah untuk mengelola lingkungan. Meskipun demikian, agar hasilnya bisa lebih optimal, diperlukan beberapa penyempurnaan dalam pelaksanaannya, antara lain sebagai berikut :

1) Perekrutan anggota stakeholder, yaitu KPPL Kawasan atau KPPL Desa perlu dilakukan sesuai dengan prinsip comanagement yaitu masyarakat diberi kebebasan untuk memilih wakil-wakilnya sendiri untuk duduk menjadi anggota. Dengan demikian masyarakat akan merasa terwakili dalam kelompok itu, dan merasa terikat dengan keputusan yang 
diambil oleh kelompok yang dibentuk.

2) Pada tingkat yang lebih tinggi, yaitu KKPK di kabupaten yang berfungsi mengkoordinasikan kelompok-kelompok stakeholder dari tingkat di bawahnya (KPPL Kawasan dan Desa), perekrutan anggotanya sebaiknya juga merupakan perwakilan dari setiap kelompok KPPL, yang ditunjuk oleh KPPL masing-masing.

3) Untuk antisipasi munculnya konflik di dalam kelompok stakeholder, maka pengelolaan kelompok stakeholder supaya lebih dilakukan secara transparan, dengan sistem kepemimpinan yang jelas. Untuk itu di dalam setiap kelompok perlu dibuat aturan main organisasi, yang mengatur tentang periode kepemimpinan, sistem pemilihan pengurus, sistem pengambilan keputusan dalam organisasi, dan system audit keuangannya

4) Setiap kelembagaan stakeholder hanya diberi tugas yang terfokus pada pengelolaan lingkungan laut dan sumberdaya perikanan yang ada, serta upaya meningkatkan kesejahteraan masyarakat yang matapencariannya tergantung pada pemanfatan sumberdaya perikanan.

5) Kelompok stakeholder yang ada diberi wewenang sepenuhnya untuk menyusun program pengelolaan lingkungannya. Tugas pemerintah adalah sebagai fasilitator bagi terwujudnya program. Bisa saja pemerintah memiliki program yang berbeda dengan yang dimiliki oleh kelompok stakeholder, namun sebaiknya mendapatkan persetujuan dari kelompok stakeholderyang bersangkutan.

6) Untuk memperkuat kelembagaan dan pelaksanaan kegiatan oleh kelompok stakeholder, kelembagaan stakeholder perlu didampingi oleh LSM. Akan tetapi, pendampingan tidak dilakukan hanya sebatas pelaksanaan kegiatan, melainkan dilakukan secara kontinyu, untuk mengevaluasi hasil kegiatan dan memberi masukan untuk perbaikannya.
Pendampingan oleh LSM dihentikan apabila memang lembaga stakeholder binaannya sudah benar-benar bisa mandiri dalam melaksanakan kegiatan sesuai dengan yang diharapkan.

7) Pendampingan untuk kegiatan yang dilakukan oleh kelompok-kelompok stakeholder, yaitu KPPL dan KUB, dilakukan oleh beberapa LSM sesuai dengan bidangnya. Akan tetapi, pelaksanaannya dilakukan secara terpadu, berdasarkan grand design yang disusun sebelumnya. Dengan demikian pendekatan antara satu LSM dengan LSM yang lain bisa saling mendukung, dan tidak terjadi tumpang tindih (over lapping).

8) Untuk memperkuat sistem atau peraturan pengelolaan yang dibuat oleh kelompok KPPL, perlu dibuat Perda untuk memberi landasan hukumnya.

9) Seluruh kegiatan yang dilakukan sebaiknya disosialisasikan kepada masyarakat luas melalui penyuluhan secara intensif, apalagi kegiatan yang berkaitan dengan pengelolaan lingkungan. Kegiatan penyuluhan secara intensif merupakan sarana yang efektif dalam mensosialisasikan visi dan misi kegiatan proyek, terlebih bahwa sebagian besar masyarakat pantai hanya berpendidikan sampai SD. Dengan penyuluhan yang intensif, maka masyarakat bisa mengetahui dan memahami masksud dan tujuan kegiatan pengelolaan sehingga mau berpartisipasi dalam kegiatan pengelolaan tersebut.

10) Sebaiknya kegiatan dalam program Cofish terus berlanjut meskipun proyek sudah berhenti. Untuk itu Pemda, dalam hal ini Dinas Kelautan dan Perikanan baik Tk I maupun Tk II dan instansi lainnya yang terkait agar mengagendakan kegiatan pendampingan selanjutnya, guna kelangsungan program kegiatan tersebut. Diharapkan pula agar dapat memperluas kegiatan ke daerah-daerah yang belum terjangkau proyek Co-fish saat ini. 


\section{DAFTAR PUSTAKA}

Adhuri, D.S., ed., 2008, "Dinamika Pengelolaan Sumberdaya Laut Di Lombok-Nusa Tenggara Barat", Jakarta, LIPIPress.

----dan Ratna Indrawasih, 2003, "Pengelolaan Sumberdaya Alam Secara Terpadu(Co-Management Sumberdaya Alam) : Pelajaran dari Praktek Pengelolaan Sumberdaya Laut di Bangka Belitung, Jawa Tengah dan Jawa Timur serta Pengelolaan Taman Nasional Lore Lindu di Sulawesi Tengah. Jakarta, PMB-LIPI.

Balay 1992, "Community Based Fisheries Management Institutions in Indonesia" Maritime Anthropological Studies 5(1) : 117.

Gordon, H.S., 1954, "Economic Theory of a Common Property Resource : The Fishery". Journal of Political Economy. $162: 124-142$.

Hardin, G., 1968, "Tragedy of The Commons" Sciences. $162: 1243-1248$.

Indrawasih,(ed), 2004, "Kebijakan Pemerintah Dalam Pengelolaan Sumberdaya Laut : Pelajaran Dari Kabupaten Rembang". Jakarta, PMBLIPI.

Jentoft, S., 1989, Fisheries Management : Dlegating Government Responsibility to Fishermen's Organizations. Marine Policy. 0308-597X/89/020137, April.

Johannes, R.E., 1978, Tradisional Marine Conservation Methods in Oceania and their Demise" Annual Review of ecology and Systematics. 9:349-364.

Pomeroy, R.S., B.M., Katon dan I. Harkes, 2001, "Conditions Affecting the Success of Fisheries Co-Management : Lessons from Asia". Marine Policy. 25. Hal. 197208.
Scott, A., 1955, "The Fishery: "The Objectives of Sole Ownership" Journal of Political Economiy. $63: 116-124$

Tim Peneliti UNRAM, 1999, Laporan Akhir : Identifikasi Keperluan Usaha Ekonomi Dalam Rangka Penghapusan Kemiskinan. Kerjasama Bagian Proyek Pengembangan Masyarakat Pantai dan Pengelolaan Sumberdaya Perikanan Nusa Tenggara Barat dengan Pusat Penelitian dan Pengembangan Pedesaan Universitas Mataram.

2004, Laporan Akhir : "Studi penilaian Sosial Ekonomi II Pengembangan Masyarakat Pantai dan Manajemen Sumberdaya Perikanan Lombok Timur, Nusa Tenggara Bara"t. Kerjasama Bagian Proyek Pengembangan Masyarakat Pantai dan Pengelolaan Sumberdaya Perikanan Nusa Tenggara Barat dengan Fakultas Ekonomi Universitas Mataram.

2000, Laporan Studi : "Penilaian Sumberdaya dan Ekologi Di Kecamatan Kruak, Kabupaten Lombok Timur". Kerjasama Direktorat Jendral Perikanan, Departemen Pertanian dengan Fakultas pertanian Universitas Mataram.

Tim Peneliti YSLPP, 2003, Laporan Akhir : "Pendampingan LSM Dalam rangka Pengelolaan Keanekaragaman Hayati". Bagian Proyek Pembangunan Masyarakat Pantai Dan Pengelolaan Sumberdaya Perikanan Nusa Tenggara Barat. 